\title{
Impact of an Interdisciplinary Food, Nutrition and Health Education Program for adolescent Brazilian volleyball players
}

\author{
Impacto de um Programa Interdisciplinar de \\ Educação Alimentar, Nutricional e em Saúde \\ para jogadoras de voleibol adolescentes
}

Natália Vilela Silva DANIEL'

Luana Pilon JÜRGENSEN ${ }^{1}$

Ricardo da Costa PADOVANI ${ }^{2}$

Claudia Ridel JUZWIAK ${ }^{3}$

\section{A B S T R A C T}

\section{Objective}

To evaluate the impact of an Interdisciplinary Food, Nutrition and Health Education Program on nutrition knowledge, intention to change eating behavior, and body dissatisfaction of adolescent volleyball players.

\section{Methods}

The sample consisted of 10 female volleyball players from the juvenile category of the city of Santos, São Paulo, Brazil, who participated in a program with eight monthly meetings (one discussion group followed by six educational activities and one final discussion group for evaluation).

\section{Results}

Nutrition knowledge, body perception, intention to change eating behavior, eating attitudes and practices were investigated using questionnaires and discussion groups before and after the athletes' participation in ludic activities designed to address nutrition strategies for athletic performance and healthy eating, and how to deal with pressure for results and self-image. Nutrition knowledge improved from $57.0 \% \pm 9.9$ to $63.0 \% \pm 11.8$ $(p=0.03)$ of correct answers. The mean body distortion score did not change $(70.0 \pm 14.9$ versus $76.5 \pm 22.4$,

\footnotetext{
1 Universidade Federal de São Paulo, Instituto de Saúde e Sociedade, Programa de Pós-Graduação Interdisciplinar em Ciências da Saúde. Campus Baixada Santista, R. Silva Jardim, 136, Vila Matias, 11015-020, Santos, SP, Brasil. Correspondência para/Correspondence to: NVS DANIEL. E-mail: <natalia.vilelasd@gmail.com>.

2 Universidade Federal de São Paulo, Instituto de Saúde e Sociedade, Departamento da Saúde, Educação e Sociedade. Santos, SP, Brasil.

${ }^{3}$ Universidade Federal de São Paulo, Instituto de Saúde e Sociedade, Departamento de Ciências do Movimento Humano. Santos, SP, Brasil.

Support: Programa Interno de Bolsas de Extensão da Universidade Federal de São Paulo.
} 
$p=0.235$ ). Six athletes advanced in their intention to change eating behavior. Positive food practices were reported during the program and the identified discourses indicated the intention of changing the daily eating habits in the future.

\section{Conclusion}

The program had a positive impact on nutrition knowledge and intention of changing eating behavior; however, for other issues, especially involving emotional aspects, further interventions should be planned.

Keywords: Athletes. Feeding behavior. Food and nutrition education.

\section{R E S U M O}

\section{Objetivo}

Avaliar o impacto de um Programa Interdisciplinar de Educação Alimentar, Nutricional e em Saúde sobre o conhecimento nutricional, a intenção de mudança de comportamento alimentar e a insatisfação corporal de jogadoras de voleibol adolescentes.

\section{Métodos}

A amostra foi composta por 10 atletas de voleibol, jogadoras da categoria juvenil da cidade de Santos, SP, que participaram do programa composto por oito encontros mensais (um grupo de discussão seguido por seis atividades educacionais e um grupo de discussão final para avaliação).

\section{Resultados}

Conhecimento nutricional, percepção corporal, intenção de mudança de comportamento alimentar, atitudes e práticas alimentares foram investigadas por questionários e grupo de discussão antes e depois da participação das atletas nas atividades lúdicas, as quais abordaram estratégias nutricionais para desempenho esportivo, alimentação saudável, lidar com pressão por resultados e percepção corporal. O conhecimento nutricional aumentou de $57,0 \% \pm 9,9$ para $63,0 \% \pm 11,8(p=0,03)$ de acerto. Não houve diferença no escore de distorção corporal $(70,0 \pm 14,9$ versus $76,5 \pm 22,4, p=0,235)$. Seis atletas avançaram na intenção de mudança de comportamento alimentar. Modificações positivas nas práticas alimentares foram relatadas durante as atividades e os discursos identificados apontam intenções de futuras mudanças nos hábitos alimentares diários.

\section{Conclusão}

O programa teve impacto positivo em aumentar o conhecimento nutricional e mudança de comportamento alimentar; porém, para outros aspectos, principalmente envolvendo questões emocionais, outras intervenções devem ser planejadas.

Palavras-chave: Atletas. Comportamento alimentar. Educação alimentar e nutricional.

\section{INTRODUCTION}

Despite the recognition of the importance of nutrition for athletic performance, inappropriate dietary intake is frequently observed in athletes ${ }^{1-3}$. This may be related to the complex process of selecting foods, which depends on biological, socioeconomic, food supply/availability, and cultural aspects ${ }^{4}$. In athletes, little access to accurate information, influence of the media, coach and peers, and the adoption of restrictive diets aimed at achieving desired weight/body composition, play particularly important roles ${ }^{5}$.
To investigate aspects that affect food choices is to look beyond the relationship between nutrition knowledge and dietary practices ${ }^{5}$; it involves investigating the factors that influence food choices, such as: food availability, social and cultural environment, beliefs, habits, body image perception, among others ${ }^{6}$. Understanding what governs these food choices allows the professional team to provide support and alternatives to motivate the adoption and maintenance of an adequate diet for athletic performance and health ${ }^{5}$. Furthermore, to know if and when athletes intend 
to change their eating habits, and only then plan the diet intervention, is also pointed out as important for the professional sports team? ${ }^{7}$.

Studies with athletes indicate the need to develop food and nutrition education programs, which enables individuals to take appropriate nutritional decisions and make autonomous food choices ${ }^{2,3,8}$. These programs should be specially designed and consider the demands of athletes ${ }^{1}$.

Considering this, the aim of this study was to qualitative and quantitatively evaluate the impact of an interdisciplinary program of Food, Nutrition and Health Education (FNHE), planned and developed according to specific demands of an adolescent female volleyball team, on some of the factors involved in their food choices (nutrition knowledge, intention to change eating behavior and body dissatisfaction).

\section{METHODS}

The Food, Nutrition and Health Education program was created based on a study that investigated nutritional issues of athletes in the city of Santos/Brazil, and which identified inappropriate food intake, nutrition knowledge gaps, food beliefs, and body dissatisfaction?. The activities were designed by an interdisciplinary group (nutrition and psychology) for a female volleyball team.

The theoretical framework comprised Freire's precepts ${ }^{10}$ and the Maguerez's Arch methodology ${ }^{11}$. From Freire ${ }^{10}$ we adopted and applied the precepts of the horizontal dialogue (without health professionals' authoritarianism), and aiming to apply theory to practice, activities were directed at promoting group discussions. As recommended by Freire ${ }^{10}$, previous knowledge and beliefs were respected and subjects were encouraged to exchange their knowledge and experiences. Activities stimulated participative actions and athletes' empowerment. The five learning steps proposed in the Maguerez's Arch methodology ${ }^{11}$ were adopted as follows: early in the process, mainly in the first group discussion, subjects were encouraged to observe their reality and identify problems and their key points (first and second steps, respectively); information was provided in the following meetings, through ludic educational activities. Adding this new knowledge to their own previous knowledge and experiences, athletes were encouraged to find solutions (third and fourth steps). Finally, they were encouraged to use the possible solutions according to their reality (fifth step). Throughout the meetings, the professional team supplied the athletes with tools to deal with and improve their daily habits. Both problematization methodological frameworks are considered important critical pedagogical approaches for health education, since they value knowledge and experience of the subjects and assist them in recognizing subsidies to transform their reality ${ }^{12}$.

The study was approved by the Research Ethics Committee of the Universidade Federal de São Paulo (n 220448/13). The sample comprised of a female volleyball team (juvenile category), which represented the city of Santos in regional and state level competitions. The athletes had three to ten years of volleyball practice, and in the study year they were among the eight best teams of São Paulo state. Out of the 14 athletes who comprised the team, 10 completed all stages of the program and were included in this study.

The program consisted of eight monthly meetings. Profile information was collected in the first meeting, whereas educational intervention activities were held in the following six meetings. In the final meeting the program impact was evaluated, both qualitatively (discourses and reported impressions) and quantitatively (statistical analysis of the questionnaires' results before and after the intervention).

The steps to plan the FNHE program were: 1) education profile assessment; 2) goal setting; 3) selection of programmatic content; 4) development of materials; 5) logistical design; 6) program evaluation process $^{13}$.

Athletes answered questions on demographic characteristics, eating habits, exercise routine, and 
socioeconomic status ${ }^{14}$. Nutrition knowledge was assessed through a validated questionnaire containing multiple-choice questions about healthy eating, food groups, and nutrient composition (macro and micronutrients), and a five-point Likert scale with 18 statements based on beliefs about sports nutrition ${ }^{7}$. Each correct answer was assigned one point, with a maximum possible score of 53 points. The transtheoretical model ${ }^{15}$ assessed the stage of intention to change eating behavior. The self-assessment instrument contains questions regarding 'when' and 'how motivated' the athlete was in planning to change and adopt a healthy diet. By a generated algorithm, participants could be categorized into one of six stages: pre-contemplation (no intention of changing behavior); contemplation (recognizing the need to change behavior and intention to do it in the next six months); preparation (she/he wants to change behavior in the next 30 days and has already taken some actions accordingly); action (changed behavior less than six months ago); maintenance (changed behavior more than six months ago); or relapse (interruption of the changed behavior and return to old practices) ${ }^{15}$.

Body dissatisfaction was identified with the body shape scale proposed by Kakeshita et al. ${ }^{16}$ for adults, which is appropriated for adolescents ${ }^{17}$. This body shape scale ranges from thinness (silhouette 1) to obesity (silhouette 15), and athletes selected the body shape that represented their "current body shape" and their "desired body shape". Dissatisfaction was given by the difference between current and desired body shapes (zero $=$ satisfaction with body image, less than zero $=$ dissatisfaction with thinness; greater than zero $=$ dissatisfaction with excessive weight). Furthermore, the Body Shape Questionnaire ${ }^{18}$ was used to classify athletes' body distortion in: "without distortion" (<80 points), "slight distortion" (<111), "moderate distortion" $(<141)$, and "severe distortion" (>141).

A group discussion was organized to complement the profile and identify athletes' demands. Through a problematization methodology, participants were stimulated to express opinions about specific topics (food attitudes, barriers, interests) ${ }^{19}$. The speeches of the group were recorded by observers and later analyzed using the Collective Subject Discourse ${ }^{20}$. This method is based on the construction of a 'collective self', that means, it reconstitutes several individual speeches of a group, gathered under central ideas, in a speech that represents the collective. From recorded speeches, key expressions were identified, deriving central ideas, which represent the content of the key expressions in a concise manner. Central ideas were grouped into categories with similar meanings and collective subject discourses were created in the first-person singular, portraying opinions on the discussed topics that represent the collective ${ }^{20}$.

Each of the six ludic activities focusing on food, nutrition, and health is summarized in Chart 1. After the six meetings, questionnaires were readministered to assess the impact of the FNHE program. Results are expressed as mean and standard deviation. The Student's t-test compared the baseline and final results of the Body Shape Questionnaire and knowledge score.

The observers took notes in all meetings ${ }^{22}$, which were used to complete the data. All notes were analyzed based on the Collective Subject Discourse method. At the final meeting, through a discussion group, athletes evaluated the program, expressing positive and negative aspects, the most meaningful messages, dietary modification throughout the process, and the intention to change eating practices after the program. This second discussion group was designed to qualitatively evaluate impressions on FNHE program.

\section{R E S U L T S}

The athletes were $17.2(\mathrm{SD}=0.94)$ years old, attended high school $(n=7)$, were classified socioeconomically as class $B(n=6)$, and had a training schedule of 16 hours/week. Six athletes 
Chart 1. Outline of the six meetings of the interdisciplinary program of Food, Nutrition, and Health Education developed with an adolescent female volleyball team, by themes, objectives, and strategies. Santos (SP), Brazil, 2015.

\begin{tabular}{|c|c|c|c|}
\hline Meeting & Theme & Educational objectives & Used strategies \\
\hline $1^{\circ}$ & Healthy diet & $\begin{array}{l}\text { To know and understand the idea of a healthy } \\
\text { diet. }\end{array}$ & $\begin{array}{l}\text { Explanation followed by a board } \\
\text { game. }\end{array}$ \\
\hline $2^{\circ}$ & Nutrition and sports performance & $\begin{array}{l}\text { To be capable of making good food choices } \\
\text { for performance. }\end{array}$ & $\begin{array}{l}\text { Discussion of eating situations relate } \\
\text { to competition (pre-game, during/ } \\
\text { immediately after, post-game meal). }\end{array}$ \\
\hline $3^{\circ}$ & $\begin{array}{l}\text { Pressure for results, anxiety and } \\
\text { eating }\end{array}$ & $\begin{array}{l}\text { To learn coping strategies to deal with sports } \\
\text { pressure. }\end{array}$ & $\begin{array}{l}\text { Discussion based on different stress } \\
\text { situations in sport. }\end{array}$ \\
\hline $4^{\circ}$ & Antioxidants in fruits and vegetables & $\begin{array}{l}\text { To know the importance and stimulate the } \\
\text { consumption of these food groups. }\end{array}$ & $\begin{array}{l}\text { Explanation followed by a game } \\
\text { ("capture the flag of antioxidants") } \\
\text { and tasting of a healthy recipe with } \\
\text { vegetables. }\end{array}$ \\
\hline $5^{\circ}$ & Energy equivalence & To know how food groups can be alternated. & Culinary workshop. \\
\hline $6^{\circ}$ & Body image and healthy food choices & $\begin{array}{l}\text { To be sensitized to making good food choices } \\
\text { and its relation with body image. }\end{array}$ & Group discussion. \\
\hline
\end{tabular}

Note: Adapted from Daniel et al. ${ }^{21}$

moved from their hometown to be part of the city's team and shared the same residence. Lunch was available at a sports club restaurant. Training and school schedule created some food intake difficulties, mainly lack of time and tiredness for cooking evening meals.

Table 1 shows the results of nutrition knowledge. The program improved the team's knowledge score $(p=0.03)$. Nutrition beliefs in sports decreased after the program, and those with fewer "believers" at the end were: "pineapple has special value in diets for weight loss because they burn fat" (from 4 to 1 athlete) and "to enhance muscle definition it is necessary to maintain a diet with little bread and potatoes" (from 7 to 2 athletes). The most present belief was protein overvaluation, with $82 \%(n=9)$ of concordant athletes before the FNHE program; notwithstanding, after the intervention only one athlete changed her opinion.

Two athletes completed the questionnaire on intention to change eating behavior incorrectly and were excluded from this analysis. The remaining athletes $(n=8)$ showed heterogeneity in the stages. Five athletes advanced at least one stage of intention to change behavior (Figure 1).
Table 1. Mean and standard deviation of correct answers in the nutrition knowledge questionnaire and percentage of nutrition beliefs in sports before and after the Food, Nutrition and Health Education program $(n=10)$.

\begin{tabular}{lrrrrrr}
\hline \multirow{2}{*}{ Nutritional aspects } & \multicolumn{2}{c}{ Before } & & \multicolumn{2}{c}{ After } \\
\cline { 2 - 3 } \cline { 6 - 7 } & \multicolumn{1}{c}{ M } & \multicolumn{1}{c}{ SD } & & M & SD \\
\hline Nutrition knowledge & 57.0 & $9.9^{*}$ & & 63.0 & $11.8^{*}$ \\
Macronutrients' questions & 72.0 & 16.6 & & 77.3 & 16.7 \\
Micronutrients' questions & 27.0 & 22.6 & & 38.0 & 24.9 \\
Food groups' questions & 98.9 & 3.5 & & 97.8 & 4.7 \\
Nutrition beliefs in sports (\%) & 70.9 & 15.9 & & 58.2 & 16.2 \\
\hline
\end{tabular}

Note: ${ }^{*} p=0.03$.

M: Mean; SD: Standard Deviation.

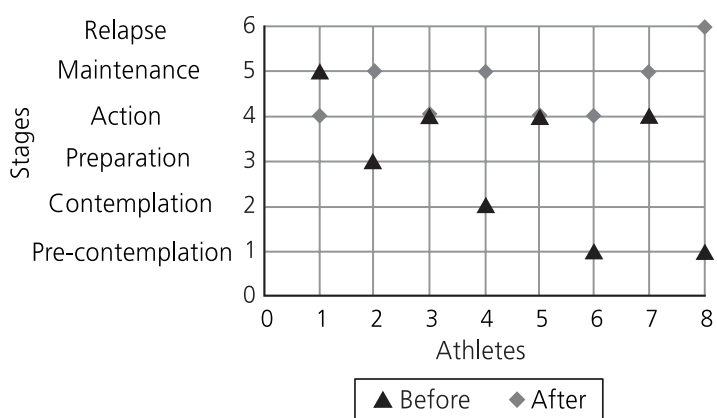

Figure 1. Distribution of athletes according to the stage of behavior change and their classifications before and after the Food, Nutrition and Health Education program $(n=8)$. Santos (SP), Brazil, 2015. 
This result was confirmed in the final meeting, when six athletes reported the intention to make future changes, emphasizing vegetable consumption, substitution of snacks for balanced meals at dinner, and reduction of sweets intake.

The program did not change the mean Body Shape Questionnaire scores $(p=0.235)$. Before the FNHE program, mild body image distortion was observed in three athletes, while the others were classified as 'without distortion'. After the program four athletes presented mild, one presented moderate, and five had no body image distortion.

Body image dissatisfaction (Figure 2) was initially observed in six athletes, and only four of them were less dissatisfied after the program. The greater the difference between current and desired body shape, the greater the degree of dissatisfaction. The magnitude of initial dissatisfaction ranged from -1 to 5 , and the final assessment ranged from -2 to 3 .

Chart 2 shows the athletes' perceptions about discussed issues and intention to change daily practices. At the fourth meeting, the coach reported having observed positive changes regarding the food brought to competitions, saying that habitual commercially-prepared snacks were replaced by homemade sandwiches and fruits. At the final meeting, nine athletes said they

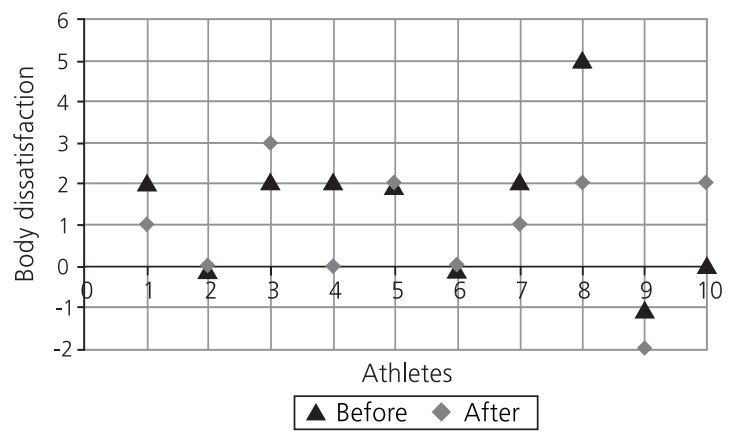

Figure 2. Body dissatisfaction before and after the Food, Nutrition and Health Education program $(n=10)$. Santos (SP), Brazil, 2015. had made dietary changes during the year: daily intake of fruits, vegetables, and breakfast; food intake before and after training (athletes who ate nothing or preferred sandwich cookies after training started eating cereal bars or fruits); decrease in high-energy, low-nutrient food intake (referred by the athletes as "junk food") throughout the day and awareness of the quantity consumed. All participants evaluated the program positively, indicating preference for ludic and participatory dynamics.

\section{DISCUSSION}

The athletes are adolescents, who study and train daily, and some live away from their families, all aspects that may influence their food choices, as well as their economic condition. Gouvea et al. ${ }^{23}$ emphasizes that in addition to socioeconomic factors, team interaction and family support should be considered.

Previous studies that analyzed the nutrition knowledge of female volleyball athletes reported similar findings $\left(55.0^{24}\right.$ and $45.0 \%^{2}$ of correct answers) compared with our pre-FNHE results (57.9\%). The main contribution of the program was to improve nutrition knowledge. An individualized dietary education provided by Valliant et al. ${ }^{2}$ also had positive impact on nutrition knowledge (increasing from 45.0 to $57.0 \%$ ). All these studies confirm that FNHE programs can contribute to nutrition knowledge.

The beliefs presented by the athletes were also found in other studies. Rosenbloom et al. ${ }^{8}$ also noted that athletes avoid carbohydrates when trying to lose weight. In another study ${ }^{25}$ the belief that pineapple helps to "burn body fat" was common among coaches, and the authors highlighted the risk of propagating this information among athletes. Protein overvaluation was also observed by Almeida \& Soares ${ }^{26}$, who analyzed the dietary profile of adolescent volleyball players.

Despite the importance of going beyond knowledge transmission when designing a FNHE 
program, in most studies, which proposed such programs for athletes, activities are planned based on generalized nutrition information ${ }^{27}$, frequent nutrition doubts presented by athletes ${ }^{27}$, or general nutrition recommendation for performance ${ }^{28}$. The present study, using the diagnosis results to design a process based on athletes' needs, was constructed to be meaningful for the group and to link the contents discussed in each activity to their reality.

Chalip ${ }^{29}$ suggests that the heuristic theory of Tversky and Kahneman can be associated with the difficulties of athletes' education process. The first factor highlighted is 'availability', when the individual, at the time of decision, considers and reacts according to what is mostly available in his/her mind. The 'representativeness' factor gives causal relation to the situations and enhances availability; therefore, by recalling an example of other successful athletes and their nutrition strategies, even receiving information that those strategies are not the most appropriate, individuals disregard the guidelines given by experts and rely on "false" claims. The third factor is called "anchor and adjust". From a formed and previous opinion any contrary information could be believed, but not considered. Although these factors hinder the FNHE process, the author outlines three strategies that will change them and affect food choices positively: a) athlete's imagination should be stimulated; b) health professionals, contrary to formed opinions, should provide other points of view, and c) athletes should identify reasons for their eating behaviors, attributing meaning to justify behavior change ${ }^{29}$. The adoption of the Maguerez's Arch methodological framework in this study allowed developing the strategies proposed by Chalip ${ }^{29}$. Furthermore, we can relate them with the problematization methodology adopted from Freire's work, which took into consideration athletes' knowledge, their active participation during the education process, and the concern to supply them with tools to deal with their reality in critical and creative ways.

Although athletes did not advance significantly through the stages of change, the observed advance is noteworthy, once it may be related to relatively stable cognitive patterns. Furthermore, the results highlight the potential of new learnings in the change process.

The final results indicated that $38 \%$ of the athletes were in "maintenance", meaning they already had made changes for at least six months, and $50 \%$ were in "action", meaning that they were in the process of changing their eating behavior (in less than six months). Knowing the stage in which the individual is classified is important to choose the intervention strategies that will assist in behavior changing ${ }^{15}$.

Public display of the body and pressure in the sports environment can lead to body dissatisfaction in athletes ${ }^{30}$. Concerns about selfimage $^{3}$ and body dissatisfaction ${ }^{31}$ were also observed in other studies with female volleyball players. Regarding body distortion (Body Shape Questionnaire) our results did not show improvement between the first and second assessments. Individually, some athletes $(n=3)$ had improved their body image perception after the program, while others ( $n=2$, apart from the 3 that initially presented body distortion) started having image distortion. Contact with such constructs throughout the intervention program may have triggered the discrimination of new self-image determinants and consequently, a reinterpreted self-assessment. Considering that there is a sociocultural construction often involved in personality structuring, the effective modification of such patterns of interpretation may not present itself. This fact does not necessarily indicate impossibility of learning new ways to deal with the situation and reduce psychological distress.

The findings on body distortion evidenced a decrease in body dissatisfaction between assessments. It is important to highlight that the body image theme was little verbalized by the athletes during the discussion groups. This fact, together with the results obtained from the instruments, may indicate some resistance from the athletes on this issue. These findings clearly show the need to consider specific models of intervention to address body image issues in female athletes. 
Chart 2. Central Ideas and Collective Subject Discourse of the meetings of the Food, Nutrition and Health Education program developed for an adolescent female volleyball team. Santos (SP), Brazil, 2015.

\begin{tabular}{|c|c|c|}
\hline Meeting & Central idea & Discourse synthesis \\
\hline & & "I'm happy when I train well and I am praised for that". \\
\hline & Pressure for results & $\begin{array}{l}\text { "I feel sad when something goes wrong and I fail at the training. I } \\
\text { don't know what to do next, but I like to be alone". }\end{array}$ \\
\hline & & $\begin{array}{l}\text { "I have little time for lunch. So I eat in a rush and make up for my } \\
\text { hunger at dinner". }\end{array}$ \\
\hline \multirow[t]{3}{*}{ Discussion Group } & Difficulty with dinner & $\begin{array}{l}\text { "Is dinner (rice, black beans, steak, etc.) very important or can we } \\
\text { have a sandwich?" }\end{array}$ \\
\hline & \multirow[t]{2}{*}{ Relevant issues identified } & "I want to know what to eat to improve performance". \\
\hline & & "I don't' like to eat vegetables". \\
\hline $1^{\circ}$ & Balanced diet & $\begin{array}{l}\text { "The thing I most liked was to know more about food, its groups and } \\
\text { roles". }\end{array}$ \\
\hline \multirow{4}{*}{$2^{\circ}$} & Breakfast habit & $\begin{array}{l}\text { "I'm not used to having breakfast because I have no time. And even } \\
\text { when I have, cycling when I'm full is hard, so I only eat after a while". }\end{array}$ \\
\hline & \multirow{2}{*}{ What I eat before and after the game } & $\begin{array}{l}\text { "When the game delays we eat what we take in our backpacks: } \\
\text { fruits, cereal bar, and juice box". }\end{array}$ \\
\hline & & $\begin{array}{l}\text { "After the game we should eat bread and juice, but we eat pizza, } \\
\text { right? It is what the coach offers and if there is nothing else I will eat } \\
\text { it, I'm not going to starve". }\end{array}$ \\
\hline & What do you intend to change in dietary habit & $\begin{array}{l}\text { "After this activity I intend to eat something right after the training } \\
\text { and during breakfast". }\end{array}$ \\
\hline \multirow{3}{*}{$3^{\circ}$} & \multirow{2}{*}{$\begin{array}{l}\text { Consumption and benefits of fruits and } \\
\text { vegetables }\end{array}$} & "I eat fruits every day, but vegetables not always". \\
\hline & & "Those foods are rich in vitamins, iron, calcium, fibers, and zinc". \\
\hline & Antioxidants & "I enjoyed knowing about antioxidants. I didn't know they existed." \\
\hline \multirow{2}{*}{$4^{\circ}$} & Pressure from the coach & $\begin{array}{l}\text { "The expectations of the coach are stressful, but he also is pressured } \\
\text { by many people. I think all this pressure is on the account of victories } \\
\text { besides the support, marketing and the great name and structure of } \\
\text { the team. If I were the coach I would put more pressure on the athlete } \\
\text { despite the risk of creating more anxiety and losing performance". }\end{array}$ \\
\hline & Responsibilities and sacrifices of an athlete & $\begin{array}{l}\text { "There are several elements involved in the life of an athlete, such as } \\
\text { fans, distance from the family, injuries, and staying on the bench. To } \\
\text { be an athlete a lot of sacrifice is needed! Take good care of the diet, } \\
\text { work well to avoid lesions, concentrate and always try to improve } \\
\text { defects". }\end{array}$ \\
\hline $5^{\circ}$ & Adequate quantity for dinner & $\begin{array}{l}\text { "I liked to gain notion about adequate amount and how a sandwich } \\
\text { can substitute a traditional meal at dinner. It is good to know how } \\
\text { much we should eat after training". }\end{array}$ \\
\hline \multirow[b]{2}{*}{$6^{\circ}$} & Prohibited food & "There are no prohibited foods, but you have to eat well". \\
\hline & Emotional status and diet & $\begin{array}{l}\text { "It was interesting to learn about the influence of emotional status } \\
\text { on food choices". }\end{array}$ \\
\hline
\end{tabular}

The discourses reported in Chart 2 reinforce the positive impact on the athletes' food practices. The discourse, "After this activity I intend to eat something right after the training and during breakfast", indicates that the lack of breakfast before a competition, identified at the beginning 
of the activity, was understood as an inappropriate habit for subsequent sports performance and may be changed, as well as the intake of a recovery snack, right after the training session, as recommended ${ }^{32}$. Athletes also became more interested in their food choices, showing interest to know about food/meal equivalence, antioxidants, and the influence of emotional status on their food choices. As the importance of good nutrition for athletic performance is well recognized ${ }^{1,5,32}$, it is essential that athletes become more aware and capable of handling their eating issues. Furthermore, data shows the importance of an interdisciplinary program in learning cognitive and emotional new skills.

An important aspect for the success of the FNHE program was athletes' adherence. The partnership with the technical staff and the fact that activities were developed at the end of the training sessions were crucial to ensure the presence of athletes in all activities. Ludic and participatory strategies (games, discussion groups, sensory analysis) were well received by the athletes.

Educational strategies appropriately created favorable conditions for reframing the participants' perceived reality, which represents an important element in the process of nutrition knowledge acquisition and behavior change.

The study highlights the need of further evaluation of the impact of an interdisciplinary FNHE program, planned specifically for athletes' requirements.

\section{CONCLUSION}

The interdisciplinary approach of the study FNHE program was designed according to the specific demands of the volleyball team, so the activities were proposed taking into account their knowledge gaps, nutrition beliefs, issues related to perceived body image, and stage of intention to change behavior. The program had a positive impact on nutrition knowledge and stage of intention to change behavior. Positive eating behavior changes were identified along the meetings: higher intake of fruits, lower intake of "junk foods", daily intake of breakfast, and awareness of the quantity consumed. The lack of results on body image issues shows that there are still challenges to be overcome.

The results should not be generalized as the study aimed to assess the potential impact of this specific intervention, designed according to athletes' needs. The small sample is a study limitation. More specific strategies, more frequent meetings, and longer activities are factors that may improve success.

\section{COLLABORATORS}

NVS DANIEL planned and applied the FNHE program, collected, analyzed, and interpreted data and wrote the article. LP JÜRGENSEN planned and applied the FNHE program, collected data, and revised the article. RC PADOVANI supervised the FNHE program, analyzed and interpreted data, and revised the article. CR JUZWIAK conceived the program, supervised the planning and application of the FNHE program, analyzed and interpreted data, wrote and revised the article.

\section{REFERENCES}

1. Panza VP, Coelho MSPH, Di Pietro PF, Assis MAA, Vasconcelos FAG. Consumo alimentar de atletas: reflexões sobre recomendações nutricionais, hábitos alimentares e métodos para avaliação do gasto e consumo energéticos. Rev Nutr. 2007; 20(6):681-92. http://dx.doi.org/10.1590/\$1415-527320070006 00010

2. Valliant MW, Emplaincourt HP, Wenzel RK, Garner $\mathrm{BH}$. Nutrition education by a registered dietitian improves dietary intake and nutrition knowledge of a NCAA female volleyball team. Nutrients. 2012; 4(6):506-16. http://dx.doi.org/10.3390/nu4060 506

3. Beals KA. Eating behaviors, nutritional status, and menstrual function in elite female adolescent volleyball players. J Am Diet Assoc. 2002; 102(9):1293-6. http://dx.doi.org/10.1016/S0002-8 223(02)90285-3

4. Estima CCP, Philippi ST, Alvarenga MS. Fatores determinantes de consumo alimentar: por que os 
indivíduos comem o que comem? Rev Bras Nutr Clín. 2009; 24(4):63-8.

5. Heaney S, O'Connor H, Naughton G, Gifford J. Towards an understanding of the barriers to good nutrition for elite athletes. Int J Sports Sci Coa. 2008; 3(3):391-401. http://dx.doi.org/10.1260/17 4795408786238542

6. Smart LR, Bisogni CA. Personal food systems of male college hockey players. Appetite. 2001; 37(1):57-70. http://dx.doi.org/10.1006/appe.2001.0408

7. Jürgensen LP, Daniel NVS, Padovani RC, Lourenço LCD, Juzwiak CR. Assessment of the diet quality of team sports athletes. Rev Bras Cineantropom Desempenho Hum. 2015; 17(3):280-90. http://dx. doi.org/10.5007/1980-0037.2015v17n3p280

8. Rosenbloom CA, Jonnalagadda SS, Skinner R. Nutrition knowledge of collegiate athletes in a division I National Collegiate Athletic Association institution. J Am Diet Assoc. 2002; 102(3):418-20. http://dx.doi.org/10.1016/S0002-8223(02)90098-2

9. Juzwiak CR, Jürgensen LP, Daniel NVS, Padovani RC, Lourenço LCD, Montesano FT. Nutrition intake and knowledge, body image perception, eating disorder risk and intention of behavior change of female Brazilian athletes. FIEP Bull. 2013; 83:148-51.

10. Ceccim RB. Pacientes impacientes: Paulo Freire. In: Brasil. Caderno de educação popular e saúde. Brasília: Secretaria de Gestão Estratégica e Participativa; 2007. p.32-45.

11. Bordenave JD, Pereira AM. Estratégias de ensino aprendizagem. Petrópolis: Vozes; 1982.

12. Pereira AFL. As tendências pedagógicas e a prática educativa nas ciências da saúde. Cad Saúde Pública. 2003; 19(5):1527-34. http://dx.doi.org/10.1590/S0 $102-311 \times 2003000500031$

13. Cervato-Mancuso AM. Elaboração de programas de educação alimentar e nutricional. In: Diez-Garcia RW, Cervato-Mancuso AM, organizadores. Mudanças alimentares e educação alimentar e nutricional. Rio de Janeiro: Guanabara-Koogan; 2011.

14. Associação Brasileira de Empresas de Pesquisa. Critério de classificação econômica Brasil. São Paulo: ABEP; 2011 [acesso 2014 dez 21]. Disponível em: www.abep.org

15. Prochaska JO, Redding CA, Evers KE. The transtheoretical model and stages of change. In: Glanz K, Rimer BK, Visvanath K, editors. Health behavior \& health education. Theory, research, and practice. San Francisco: Jossey-Bass; 2008.

16. Kakeshita IS, Silva AIP, Zanatta DP, Almeida SS. Construção e fidedignidade teste-reteste de escalas de silhuetas brasileiras para adultos e crianças. Psic
Teor Pesq. 2009; 25(2):263-70. http://dx.doi.org/ 10.1590/S0102-37722009000200015

17. Laus MF, Almeida SS, Murarole MB, Braga-Costa TM. Estudo de validação e fidedignidade de escalas de silhuetas brasileiras em adolescentes. Psic Teor Pesq. 2013; 29(4):403-9. http://dx.doi.org/10.15 90/S0102-37722013000400006

18. Cordás TA, Castilho S. Imagem corporal nos transtornos alimentares. Instrumento de avaliação: Body Shape Questionnaire. Psiquiatr Biol. 1994; 2:17-21.

19. Arboleda LM. El grupo de discusión como aproximación metodológica en investigaciones cualitativas. Rev Fac Nac Salud Pública. 2008; 26(1):69-77.

20. Lefèvre F, Lefèvre AMC. Pesquisa de representações sociais: um enfoque qualiquantitativo. Brasília: Liberlivro; 2010.

21. Daniel NVS, Jürgensen LP, Lourenço LCD, Padovani RC, Juzwiak CR. Development process of a food and nutrition education program for adolescent Brazilian volleyball players. FIEP Bull. 2013; 83:76-9.

22. Minayo MCS. O desafio do conhecimento. $12^{\mathrm{a}}$ ed. São Paulo: Hucitec; 2010.

23. Gouvea FL, Beisiegel MR, Fonseca Neto DR, Oliveira MMA, Lopes MBS. Carga psíquica em situações de jogo: avaliação em equipes masculinas e femininas de voleibol infanto-juvenil. Salusvita. 2004; 23(1):63-76.

24. Moss OA. Nutrition knowledge assessment of NCAA Division I Big Sky Conference female volleyball players. Skyline. 2013; 1(1):1-14.

25. Juzwiak CR, Ancona-Lopez F. Evaluation of nutrition knowledge and dietary recommendations by coaches of adolescent brazilian athletes. Int J Sport Nutr Exerc Metab. 2004; 14(2):222-35.

26. Almeida TA, Soares EA. Nutritional and anthropometric profile of adolescent volleyball athletes. Rev Bras Med Esporte. 2003; 9(4):198203. http://dx.doi.org/10.1590/S1517-86922003 000400002

27. Molina-López J, Molina JM, Chirosa LJ, Florea D, Sáez L, Jiménez J, et al. Implementation of a nutrition education program in a handball team; consequences on nutritional status. Nutr Hosp. 2013; 28(3):1065-76. http://dx.doi.org/10.3305/nh. 2013.28.4.6600

28. Martinelli L. The implementation and evaluation of a nutrition education programme for university elite athletes. Prog Nutr. 2013; 15(2):71-80.

29. Chalip L. Enhancing the efficacy of nutrition education and counseling for athletes. EAS Academy; 2012 [cited 2015 Sept 14]. Available from: http://static. abbottnutrition.com 
30. Krentz EM, Warschburger P. Sports-related correlates of disordered eating in aesthetic sports. Psychol Sport Exerc. 2011; 12(4):375-82. http://dx. doi.org/10.1016/j.psychsport.2011.03.004

31. Bissochi CO, Juzwiak CR. Nutritional and body selfimage perception assessment of female adolescent volleyball athletes. Nutrire. 2012; 37(1):34-53. http://dx.doi.org/10.4322/nutrire.2012.004
32. American College of Sports Medicine, American Dietetic Association, Dietitians of Canada. Nutrition and athletic performance. Med Sci Sports Exerc. 2009; 41(3):709-31. http://dx.doi.org/10.1249/ MSS.0b013e31890eb86

Received: October 2, 2015

Final version: January 25, 2016

Approved: April 15, 2016 
